Article

\title{
Removal of Tetracycline Pollutants by Adsorption and Magnetic Separation Using Reduced Graphene Oxide Decorated with $\alpha-\mathrm{Fe}_{2} \mathrm{O}_{3}$ Nanoparticles
}

\author{
Adriana Magdalena Huízar-Félix ${ }^{1}$, Celia Aguilar-Flores ${ }^{1}$, Azael Martínez-de-la Cruz ${ }^{1}$, \\ José Manuel Barandiarán ${ }^{2}$, Selene Sepúlveda-Guzmán ${ }^{1, * \mathbb{C}}$ and Rodolfo Cruz-Silva ${ }^{3}$ \\ 1 Facultad de Ingeniería Mecánica y Eléctrica, FIME, Universidad Autónoma de Nuevo León, UANL, \\ Ave. Pedro de Alba s/n, Ciudad Universitaria, C.P. 66455 San Nicolás de los Garza, N.L., Mexico; \\ adriana.mhuizarf@gmail.com (A.M.H.-F.); chemistry.aguilar@gmail.com (C.A.-F.); \\ azael70@gmail.com (A.M.-d.-1.C.) \\ 2 Departamento de Electricidad y Electrónica, Universidad del País Vasco (UPV/EHU), 48940 Leioa, Spain; \\ manub@we.lc.ehu.es \\ 3 Global Aqua Innovation Center and Institute of Carbon Science and Technology, \\ Shinshu University 4-17-1 Wakasato, Nagano 380-8553, Japan; rcruzsilva.rcen@gmail.com \\ * Correspondence: selene.sepulvedagz@uanl.edu.mx; Tel.: +52-8183-29400
}

Received: 31 December 2018; Accepted: 21 February 2019; Published: 26 February 2019

check for updates

\begin{abstract}
Nanocomposites of reduced graphene oxide (RGO) with ferromagnetic $\alpha-\mathrm{Fe}_{2} \mathrm{O}_{3}$ nanoparticles have been prepared in-situ by thermal treatment. The structure and morphology of the hybrid material were studied by X-ray photoelectron spectroscopy, Raman, X-ray diffraction, and transmission electron microscopy. The results show a hybrid material highly modified with $\alpha-\mathrm{Fe}_{2} \mathrm{O}_{3}$ nanoparticles distributed on the graphene surface. The adsorption kinetics show the presence of $\alpha-\mathrm{Fe}_{2} \mathrm{O}_{3}$ nanoparticles on the RGO surface, and the amount of remaining functional groups dominated by ionization and dispersion. The adsorption kinetics of this adsorbent was characterized and found to fit the pseudo-second-order model. The $\alpha-\mathrm{Fe}_{2} \mathrm{O}_{3}$ nanoparticles on RGO modify the electrostatic interaction of RGO layers and tetracycline, and adsorption properties decreased in the hybrid material. Adsorption isotherms fit with the Langmuir model very well, and the maximum capacity adsorption was $44.23 \mathrm{mg} / \mathrm{g}$ for RGO and $18.47 \mathrm{mg} / \mathrm{g}$ for the hybrid material. Magnetic characterization of the hybrid material shows ferromagnetic behavior due to the nanosize of $\alpha-\mathrm{Fe}_{2} \mathrm{O}_{3}$ with a saturation magnetization, $\mathrm{Ms}=7.15 \mathrm{Am}^{2} / \mathrm{kg}$, a remanence $\mathrm{Mr}=2.29 \mathrm{Am}^{2} / \mathrm{kg}$, and a coercive field, $\mathrm{Hc}=0.02 \mathrm{~T}$.
\end{abstract}

Keywords: antibiotic contaminants; electrostatic interactions; magnetic removal

\section{Introduction}

Antibiotics have become an important water pollutant owing their intense use over the past decades. Since their introduction in 1950, tetracyclines are one of the major types of antibiotics, besides sulfonamides, macrolides, and quinolones that have been extensively used in human and veterinary medicines and as growth promoters in agriculture and aquaculture [1]. The third generation tetracyclines were approved by the Food and Drug Administration in 2005 and after a decade of clinical use, remain relatively active against many multidrug resistance pathogens including Staphylococcus aureus, Acinetobacter baumannii, Klebsiella pneumoniae, and Escherichia coli [2]. There are many pathways for the environmental release of antibiotics, but in general, any anthropogenic activity which demands its use has exposed it to the contamination of soils and sediments and passed it to subsurface water, lakes, and rivers [3]. Studies have warned about the potential ecological risks and public health threat 
due to the increased antibiotic resistance of gens and bacteria that leads to a bigger issue since they cannot be easily eliminated [4]. The occurrence of tetracyclines in surface water and soils is becoming a worldwide issue, and the toxicity effect eventually will reach the ecosystems [3,5]. The more significant techniques to remove micropollutants from contaminated media include adsorption, biodegradation, photodegradation, and the advanced oxidation process [6]. Some of them face many challenges due to their high operational costs and time-consuming processes. Adsorption is an inexpensive technique easy to implement, with high efficiency, and without toxic by-products. The effectiveness of the adsorption process depends on the physicochemical properties of the adsorbent, such as specific surface area, porosity, surface polarity, and morphology of the material, as well as the characteristics of the adsorbate, such as size, polarity, ionic charge, and hydrophobicity. The adsorption mechanisms consist of the electrostatic interaction and physical bindings of adsorbate to the specific sites on the surface of an adsorbent $[7,8]$. Activated carbons are frequently used as adsorbent owing to the high specific surface area, pore size, and chemical functionalities [9]. In recent years, nanocarbons, including carbon nanotubes (CNT) and graphene-like materials, have been widely applied as adsorbents for several organic contaminants including antibiotics [8]. Graphene consists of graphitic carbon sheets with a hexagonal structure of carbon atoms linked together by $\mathrm{sp}^{2}$ bonds and which exhibit excellent mechanical and physical properties [10]. Graphene can be obtained by bottom-up methods, such as epitaxial growth and chemical vapor deposition. However, top-down approaches, such as the mechanical and chemical exfoliation, are the most convenient methods for large production of graphene-type materials [11]. Graphene oxide (GO) results from the chemical oxidation of graphite and subsequent exfoliation, leading in a modified graphene with a large number of oxygen functional groups (carboxyl, hydroxyl, carbonyl, and epoxy) adding $\mathrm{sp}^{3}$ domains to the structure [12]. GO can be reduced to remove oxygen content restoring the conjugated structure and increasing the electrical properties [13]. Graphene-based materials are promising candidates as adsorbents due to good chemical stability, large surface area, and the remaining functional groups as well the domains of conjugated $\pi$ structure which allow the strong interaction between the surface of graphene and pollutants. Recently, the adsorption of tetracycline on nanocarbons materials have been reported (Table 1). Pristine and modified CNT have been used for the removal of tetracycline through adsorptive interactions, such as $\pi-\pi$ electron-donor-acceptor interactions and cation $-\pi$ bonding $[14,15]$. However, the most graphene-based material used for adsorption of tetracycline (TC) is GO and GO composites trough chemisorption via $\pi-\pi$ interaction and cation $-\pi$ bonding and the reported data (Table 1$)$ also show that the addition of a second phase impact on the adsorption properties, such as $Q_{\max }$ and adsorption conditions ( $\mathrm{pH}$ and temperature) $[16,17]$. Macroporous polystyrene/GO composites showed a high adsorption capability of tetracycline at $\mathrm{pH} 6$ and resulted in an effective recyclable adsorbent [18]. In addition, GO modified with metal oxide or metal nanoparticles have been studied as adsorbents for several antibiotics and in some cases, exhibit a positive effect, however, some of them reduce the specific area and adsorption sites. Nevertheless, modified GO is desirable for the presence of functionalities that in turn can improve the removal system promoting degradation and ease separation from the solution [19-21]. The photocatalytic degradation of TC has been reported using GO modified with $\mathrm{TiO}_{2} / \mathrm{Fe}_{2} \mathrm{O}_{3}$ nanoparticles as a magnetic adsorbent and catalyst [22]. The magnetic separation is a simple method based on the selective recovery of the magnetic adsorbents using a magnetic field and has been reported for several carbonaceous materials [23,24]. Magnetic composites of GO with paramagnetic electrolytes were prepared by electrostatic interactions and then used as adsorbent for TC removal [25]. In addition, the adsorption of TC and heavy metal ions on reduced graphene oxide (RGO) with different oxidation degrees and modified with $\mathrm{Fe}_{3} \mathrm{O}_{4}$ nanoparticles has been recently reported [26]. The reports show that functionalities and adsorption properties of reduced graphene oxide are modified by the preparation method that impacts their surface chemistry due to the presence of oxygen and nitrogen functionalities. RGO exhibits a low number of oxygen functional groups to provide an electric charge in aqueous media. However, adding additional nanostructures might expand the surface chemistry and physical properties to generate interesting adsorbents. Few works 
have been focused on the study of the structure of modified RGO and the adsorption properties of organic materials. In this work, the in situ synthesis of a hybrid material of reduced graphene oxide and $\alpha-\mathrm{Fe}_{2} \mathrm{O}_{3}$ nanoparticles is presented, and the structure and morphology were studied by spectroscopy and electron microscopy techniques. In addition, the adsorption properties of the hybrid materials were studied as a function of $\mathrm{pH}$ using tetracycline in aqueous medium. The magnetic properties of the nanocomposite were also evaluated to study the potential as magnetic removal adsorbent.

Table 1. Summary of Tetracycline adsorption on carbon nanomaterials and composites.

\begin{tabular}{|c|c|c|c|c|}
\hline Adsorbent & $Q_{\max }\left(\mathrm{mg} \mathrm{g}^{-1}\right)^{1}$ & Adsorption Conditions & Additional Functionality & Reference \\
\hline GO & 322.43 & $298 \mathrm{~K} ; \mathrm{pH} 3.6$ & & [17] \\
\hline GO & 313.48 & $298 \mathrm{~K} ;$ pH 3.6 & & [16] \\
\hline CNT & 269.54 & $293 \mathrm{~K} ; \mathrm{pH} 4.5-7$ & & [15] \\
\hline MWCNT & 364.37 & $298 \mathrm{~K}$ & & [27] \\
\hline Hydroxyapatite/GO & 16.16 & $293 \mathrm{~K} ;$ pH 5-6 & Photocatalytic oxidation & [28] \\
\hline $\mathrm{Fe}_{3} \mathrm{O}_{4} / \mathrm{GO}$ & 1272.45 & $313 \mathrm{~K} ; \mathrm{pH} 4$ & Magnetic removal & [29] \\
\hline $\mathrm{Fe} / \mathrm{Cu} / \mathrm{GO}$ & 302.5 & pH 5-7 & Magnetic removal & [20] \\
\hline $\mathrm{Fe}_{3} \mathrm{O}_{4} / \mathrm{GO}$ sponge & 473 & $308 \mathrm{~K} ; \mathrm{pH} 3$ & Magnetic removal & {$[30]$} \\
\hline
\end{tabular}

\section{Materials and Methods}

\subsection{Materials}

Graphite (natural flakes), tetracycline hydrochloride (CAS 64-75-5), and $\mathrm{FeCl}_{3} \cdot 6 \mathrm{H}_{2} \mathrm{O}$ (ACS reagent, 97\%) were purchased from Sigma-Aldrich (Toluca, Mexico). GO was obtained by oxidizing graphite through Marcano's method [12]. Other chemicals used to prepare buffer solutions were of analytical reagent grade and used without further purification. Deionized water was used in all experiments.

\subsection{Synthesis of $\mathrm{RGO}$ and $\alpha-\mathrm{Fe}_{2} \mathrm{O}_{3} / \mathrm{RGO}$ Hybrid Materials}

A GO paper was obtained by casting of a GO dispersion $(3 \mathrm{mg} / \mathrm{mL})$ in a petri-dish and dried at room temperature. RGO resulted from the thermal treatment of a GO paper at $700{ }^{\circ} \mathrm{C}$ for $2 \mathrm{~h}$ using a heating rate of $5{ }^{\circ} \mathrm{C} / \mathrm{min}$ under $\mathrm{N}_{2}$ flow. The modified $\mathrm{RGO}$ decorated with iron oxide nanoparticles was obtained by the simultaneous thermal reduction of $\mathrm{GO}$ paper loaded with $\mathrm{FeCl}_{3} \cdot 6 \mathrm{H}_{2} \mathrm{O}$ as an iron oxide precursor. A mass ratio of 1:1 of RGO:Fe was aimed for considering about $63 \%$ mass loss of GO during the thermal treatment at $700{ }^{\circ} \mathrm{C}$. The GO loaded with $\mathrm{FeCl}_{3} \cdot 6 \mathrm{H}_{2} \mathrm{O}$ was prepared by casting and then thermal treatment at $700{ }^{\circ} \mathrm{C}$ for $2 \mathrm{~h}$ under $\mathrm{N}_{2}$ flow using a heating rate of $5{ }^{\circ} \mathrm{C} / \mathrm{min}$. A schematic illustration for the one-step synthesis of $\alpha-\mathrm{Fe}_{2} \mathrm{O}_{3} / \mathrm{RGO}$ nanocomposites is shown in Figure 1a. After thermal treatment, the material was subjected to three centrifugation/redispersion cycles with deionized water and dried at $40{ }^{\circ} \mathrm{C}$ during $24 \mathrm{~h}$.

\subsection{Adsorption Experiments of Tetracycline on $\mathrm{RGO}$ and $\alpha-\mathrm{Fe}_{2} \mathrm{O}_{3} / \mathrm{RGO}$ Hybrid Materials}

Kinetic studies were carried out using a $0.6 \mathrm{mg} / \mathrm{mL}$ of adsorbent and a concentration of tetracycline in the range of 30 to $8 \mathrm{mg} / \mathrm{L}$. The kinetics experiments were performed for different $\mathrm{pH}$ of the media $(4,7$, and 10) and acquiring the absorbance at $357 \mathrm{~nm}$ for $90 \mathrm{~min}$. Adsorption isotherms of tetracycline on $\mathrm{RGO}$ and $\alpha-\mathrm{Fe}_{2} \mathrm{O}_{3} / \mathrm{RGO}$ hybrid material were carried out varying the tetracycline concentration (2-25 mg/L) in different $\mathrm{pH}$ buffer solutions $(4,7$, and 10) using $3 \mathrm{mg}$ of adsorbent in a $7 \mathrm{~mL}$ cell. The dispersion was separated by centrifugation and adsorption of the supernatant was measured after $2 \mathrm{~h}$ to reach the equilibrium conditions. 

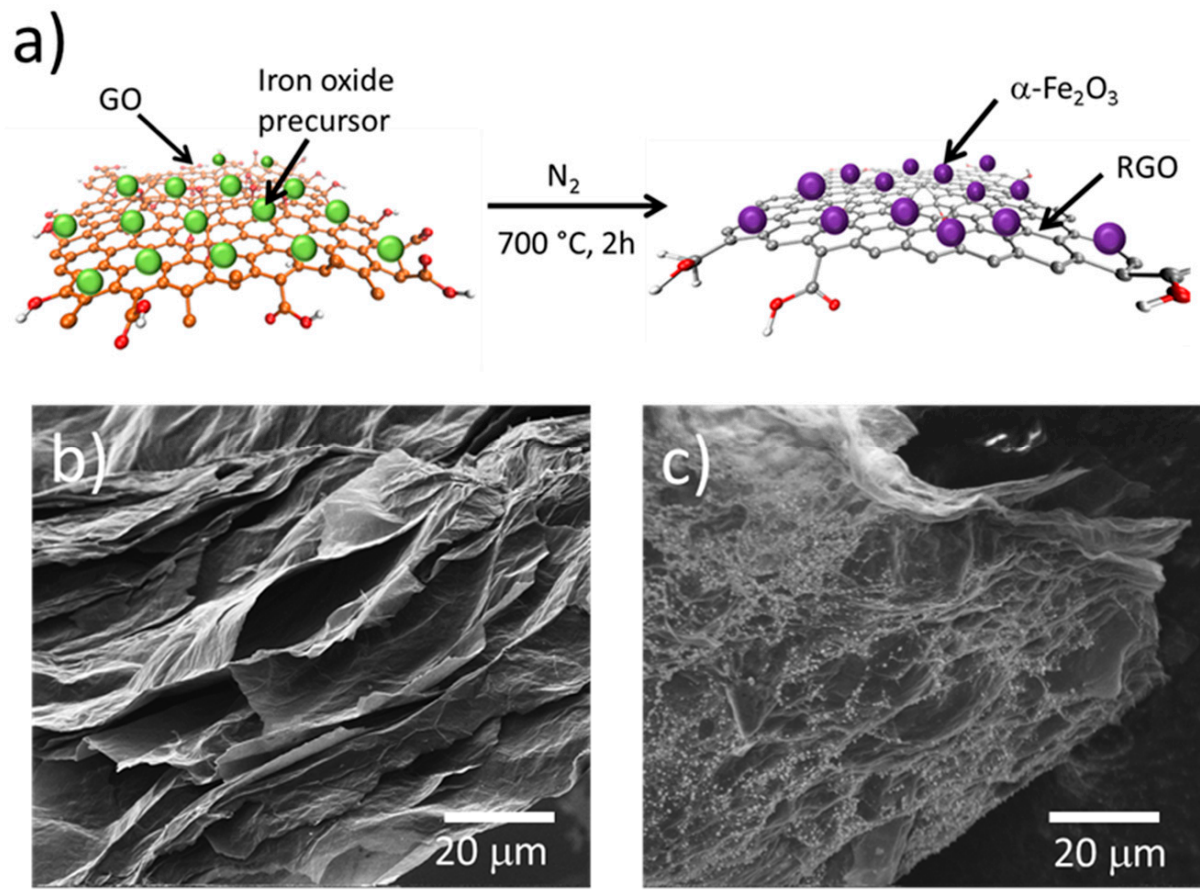

Figure 1. (a) Schematic of production of $\alpha-\mathrm{Fe}_{2} \mathrm{O}_{3} / \mathrm{RGO}$ hybrid material by the simultaneous thermal reduction of graphene oxide (GO) and synthesis of iron oxide nanoparticles; (b) Scanning electron microscopy (SEM) image of RGO prepared by the thermal reduction at $700{ }^{\circ} \mathrm{C}$ as control and (c) SEM image of the resulting $\alpha-\mathrm{Fe}_{2} \mathrm{O}_{3} / \mathrm{RGO}$ hybrid material.

\subsection{Characterization $\alpha-\mathrm{Fe}_{2} \mathrm{O}_{3} / \mathrm{RGO}$ Hybrid Materials}

X-ray diffraction (XRD) analysis for all samples was performed using a Bruker D8 Advance powder diffractometer (Billerica, MA, USA) with $\mathrm{Cu}$ radiation. The diffraction patterns were acquired between $5^{\circ}$ and $90^{\circ}$ of $2 \theta$, with a scan rate of $0.5^{\circ} / \mathrm{min}$ and an incident wavelength of $0.154 \mathrm{~nm}(\mathrm{Cu}$ $\mathrm{K} \alpha$ ). Fourier-transform infrared spectroscopy (FTIR) measurements were carried out in a Thermo Scientific Nicolet 6700 FTIR spectrometer (Waltham, MA, USA) with a wavelength range of $4000 \mathrm{~cm}^{-1}$ to $400 \mathrm{~cm}^{-1}$ in transmission mode by using $\mathrm{KBr}$ pellets. Scanning electron microscopy (SEM) characterization was performed in an FEI NOVA NANOSEM 200 (Hillsboro, OR, USA) at $10 \mathrm{KV}$ of accelerating voltage and $5 \mathrm{~mm}$ of working distance. Transmission electron microscopy (TEM) images were obtained in an FEI Titan G2 80-300 TEM (Hillsboro, OR, USA) with an accelerating voltage of $300 \mathrm{KV}$. A drop of either RGO or $\alpha-\mathrm{Fe}_{2} \mathrm{O}_{3} / \mathrm{RGO}$ aqueous dispersions was dried onto a Lacey Silicon film on a copper grid. Raman spectroscopy measurements were done using a Thermo Fisher Scientific DRX Raman Microscope (Waltham, MA, USA) with a laser line of $520 \mathrm{~nm}$ in the range of $50 \mathrm{~cm}^{-1}$ to $3500 \mathrm{~cm}^{-1}$. The samples were placed directly in the sample holder. The chemical surface composition of the samples was studied by X-ray photoelectron spectroscopy (XPS) using a Thermo Scientific K-Alpha- X-ray Photoelectron Spectrometer System (Waltham, MA, USA). The analysis was done with monochromatized $\mathrm{Al} \mathrm{K} \alpha$ radiation $(\mathrm{E}=1486.68 \mathrm{eV})$. The analysis was carried out acquiring the survey spectra with a pass energy of $200 \mathrm{eV}$ and the high-resolution core-level spectra for $\mathrm{C} 1 \mathrm{~s}, \mathrm{O} 1 \mathrm{~s}$, and $\mathrm{Fe} 2 \mathrm{p}$ using a pass energy of $30 \mathrm{eV}$ under ultra-high vacuum conditions. The adsorption kinetic of tetracycline in RGO and $\alpha-\mathrm{Fe}_{2} \mathrm{O}_{3} /$ RGO were monitored in situ using a Cary 5000 UV-Vis-NIR Spectrophotometer. Magnetic measurements were carried out using a Vibrating Sample Magnetometer (VSM developed at the University of the Basque Country, Leioa, Spain) mounted onto a Cryogenics platform for magnetic measurements with a superconducting magnet of $14 \mathrm{~T}$, a vibration frequency of $20 \mathrm{~Hz}$, sensitivity of $10^{-6} \mathrm{emu}$ with a preamplifier of $5 \mathrm{~s}$ average. 


\section{Results}

\subsection{Synthesis of $\alpha-\mathrm{Fe}_{2} \mathrm{O}_{3} / \mathrm{RGO}$}

Thermal treatment of GO has been long known as a method to reduce graphene oxide. It can be carried out in a wide range of temperatures; however, the microstructure of resulting RGO is strongly affected by the reduction conditions. FTIR analysis shows that after reduction at $700{ }^{\circ} \mathrm{C}$, only a small amount of oxygen functional groups which correspond to $\mathrm{C}=\mathrm{O}$ (carbonyl), $\mathrm{C}-\mathrm{O}$ (carboxyl), and $\mathrm{C}-\mathrm{O}$ (epoxide), besides $\mathrm{C}=\mathrm{C}$ (Figure S1) remains on the RGO. The remaining functionalities, mainly at the edges of the RGO sheets, make possible the electrostatic interaction in addition to the $\pi-\pi$ interactions with organic molecules, inorganic materials and atoms/ions [31]. The synthesis of modified RGO sheets by thermal treatment of GO paper loaded with metal oxide precursor was carried out by thermal treatment. The electrostatic interaction between oxygen functional groups of GO and $\mathrm{Fe}^{+3}$ ions is well-known, and allows the nucleation and growth of nanoparticles on the RGO surface during the thermal treatment, and the iron oxide nanoparticles result from the reaction between $\mathrm{Fe}^{+3}$ ions and the released oxygen from GO during the thermal reduction, as shown in Figure 1a. The SEM image in Figure 1b shows the homogeneous distribution of iron oxide particles on the $\alpha-\mathrm{Fe}_{2} \mathrm{O}_{3} / \mathrm{RGO}$ composite surface, very different from the RGO sample that shows a surface free of particles (Figure 1b,c). Even though thermal treatment of GO is accompanied by the elimination of $\mathrm{H}_{2} \mathrm{O}$ and $\mathrm{CO}_{2}$ that promote exfoliation, there are still thick sheets attributed to restacked RGO sheets.

\subsection{Microstructural Characterization of $\alpha-\mathrm{Fe}_{2} \mathrm{O}_{3} / \mathrm{RGO}$ Hybrid Materials}

The GO diffraction pattern exhibits a reflection peak about $10.5^{\circ}$ of $2 \theta$ associated to the 001 spacing of $0.84 \mathrm{~nm}$ of the GO sheets. After thermal reduction, the XRD diffraction pattern shows a broad peak with a maximum at $26.7^{\circ}$ corresponding to a turbostratic structure with a mean spacing of $3.4 \AA$ (Figure 2a). For the $\mathrm{FeCl}_{3} \cdot 6 \mathrm{H}_{2} \mathrm{O} / \mathrm{GO}$ hybrid paper, a shift of the $\mathrm{GO} 001$ peak to a lower diffraction angle, due to an increment in the spacing due to the presence of the iron chloride salt, was observed. The respective diffraction pattern shows small peaks corresponding to the $\mathrm{FeCl}_{3} \cdot 6 \mathrm{H}_{2} \mathrm{O}$ used as an iron oxide precursor. After thermal reduction, the XRD analysis shows that the $\mathrm{FeCl}_{3} \cdot 6 \mathrm{H}_{2} \mathrm{O} / \mathrm{GO}$ nanocomposite paper was reduced to a hybrid material of turbostratic RGO loaded with iron oxide nanoparticles with rombohedrical crystalline structure of $\alpha-\mathrm{Fe}_{2} \mathrm{O}_{3}$ according to the presence of two intense peaks at $33.15^{\circ}$ and $35.6^{\circ}$, associated to the (104) and (110) planes respectively (JCPDS-PDF card 330664). The broad signal with a maximum at $25.6^{\circ}$ corresponds to a turbostractic plane RGO which is broader than that of the pure RGO due to the presence of nanoparticles between the sheets that result in a more disordered carbonaceous structure.

Figure $2 \mathrm{~b}$ shows the Raman spectra of $\mathrm{GO}, \mathrm{RGO}, \mathrm{FeCl}_{3} \cdot 6 \mathrm{H}_{2} \mathrm{O} / \mathrm{GO}$, and $\alpha-\mathrm{Fe}_{2} \mathrm{O}_{3} / \mathrm{RGO}$ hybrid material. The spectra display mainly two intense and broad peaks at $1344 \mathrm{~cm}^{-1}$ and $1589 \mathrm{~cm}^{-1}$, which correspond to the D band and $\mathrm{G}$ band of carbon, respectively. The $\mathrm{G}$ band is associated with the first-order scattering of the E2g mode observed for $\mathrm{sp}^{2}$ carbon domains, and the D band is associated with structural defects or edges that break the symmetry and selection rule [32]. This suggests that all samples contain highly disordered and graphitic layers. The intensity ratio of $\mathrm{D}$ band to $\mathrm{G}$ band (ID/IG) is used as a measure of the disorder. The ID/IG ratio for the $\alpha-\mathrm{Fe}_{2} \mathrm{O}_{3} / \mathrm{RGO}$ hybrid material is higher than that of RGO suggesting that the nanoparticles increase the structural disorder of the hybrid material. 

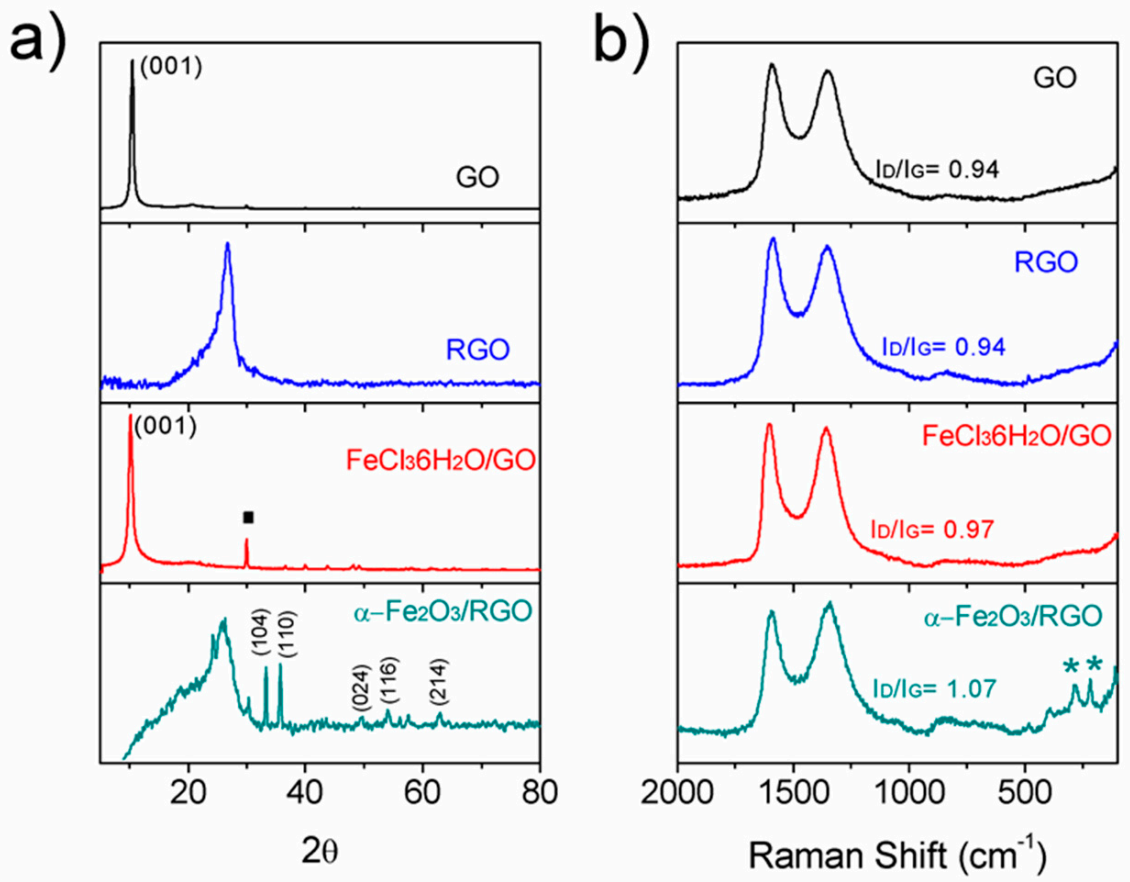

Figure 2. (a) X-ray diffraction (XRD) patterns of $\mathrm{GO}$, reduced graphene oxide ( $\mathrm{RGO}$ ), $\mathrm{FeCl}_{3} \cdot 6 \mathrm{H}_{2} \mathrm{O} / \mathrm{GO}$, and $\alpha-\mathrm{Fe}_{2} \mathrm{O}_{3} / \mathrm{RGO}$ hybrid material, planes and crystalline phases are marked; and (b) the Raman spectra of $\mathrm{GO}, \mathrm{RGO}, \mathrm{FeCl}_{3} \cdot 6 \mathrm{H}_{2} \mathrm{O} / \mathrm{GO}$, and $\alpha-\mathrm{Fe}_{2} \mathrm{O}_{3} / \mathrm{RGO}$ hybrid material showing the microstructural characterization.

Microstructural characterization was also studied by TEM (Figure 3). The low magnification image of the RGO sample (Figure 3a), used as control, shows a layered structure with a lateral size larger of $1 \mu \mathrm{m}$ and wrinkled morphology typical of RGO. The absence of crystalline domains in the high-resolution TEM (HRTEM) image of RGO (Figure 3b) and the respective selected area electron diffraction pattern (Figure 3c) showing two rings, confirm the disordered structure resulting from the short-time and low-temperature thermal treatment. The study of $\alpha-\mathrm{Fe}_{2} \mathrm{O}_{3} / \mathrm{RGO}$ hybrid material by TEM shows the wide particle size distribution of $\alpha-\mathrm{Fe}_{2} \mathrm{O}_{3}$ nanoparticles dispersed on the RGO surface, the particle sizes range from $2 \mathrm{~nm}$ to $50 \mathrm{~nm}$. The TEM image at low magnification show RGO layer with agglomerates of $\alpha-\mathrm{Fe}_{2} \mathrm{O}_{3}$ nanoparticles (Figure 3d). The wide particle size distribution is common in composite materials prepared by in situ techniques, but this method is simple and allows large-scale production, and avoids the use of chemical reducing agents. HRTEM image shows smaller crystalline $\alpha-\mathrm{Fe}_{2} \mathrm{O}_{3}$ nanoparticles attached to the RGO sheet showing a large number of nanoparticles consistent with the amount of metal oxide precursor added. The selected-area electron diffraction (SAED) presents diffraction spots associated with (214), (110), (024), and (104) planes in the rhombohedral crystalline structure of $\alpha-\mathrm{Fe}_{2} \mathrm{O}_{3}$ and two diffraction rings associated with the RGO structure.

Surface chemical composition was carried out by XPS analysis (Figure 4). Survey spectra (Figure 4a) shows that the elemental composition of GO and RGO samples consist of $C$ and O. However, RGO spectrum exhibits a lower contribution of oxygen due to the removal after thermal treatment. The spectra for the $\mathrm{FeCl}_{3} \cdot 6 \mathrm{H}_{2} \mathrm{O} / \mathrm{GO}$ and $\alpha-\mathrm{Fe}_{2} \mathrm{O}_{3} / \mathrm{RGO}$ samples present additional contribution of $\mathrm{Cl}$ and $\mathrm{Fe}$, associated with traces of the precursor and iron oxide nanoparticles. In addition, there is no significant change in the oxygen contribution due to the presence of iron oxide. 

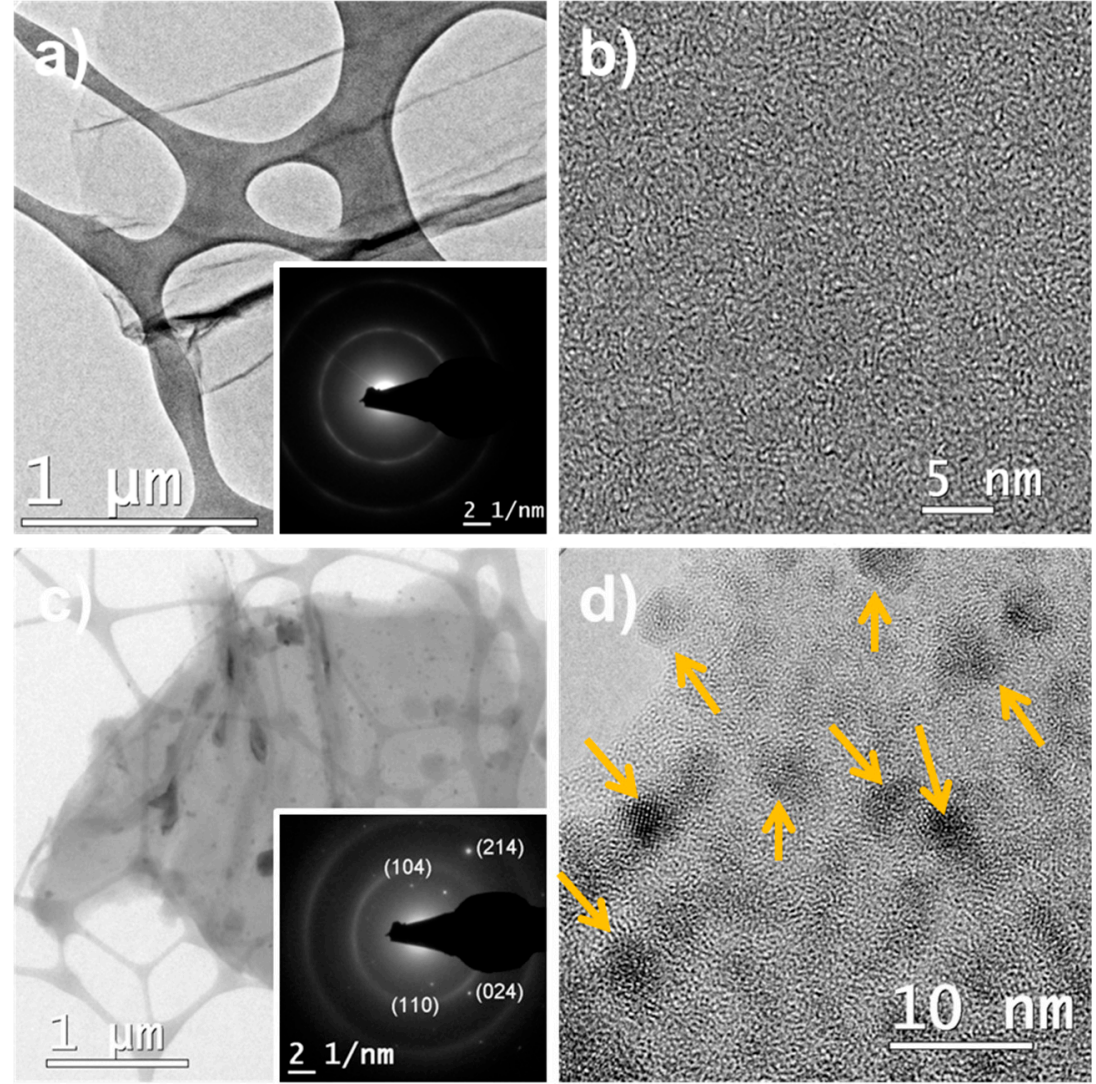

Figure 3. Transmission electron microscopy (TEM) analysis of (a,b) RGO as control and (c,d) $\alpha-\mathrm{Fe}_{2} \mathrm{O}_{3} / \mathrm{RGO}$ hybrid material. Insets in (a) and (c) show the selected-area electron diffraction (SAED) analysis for the respective materials.
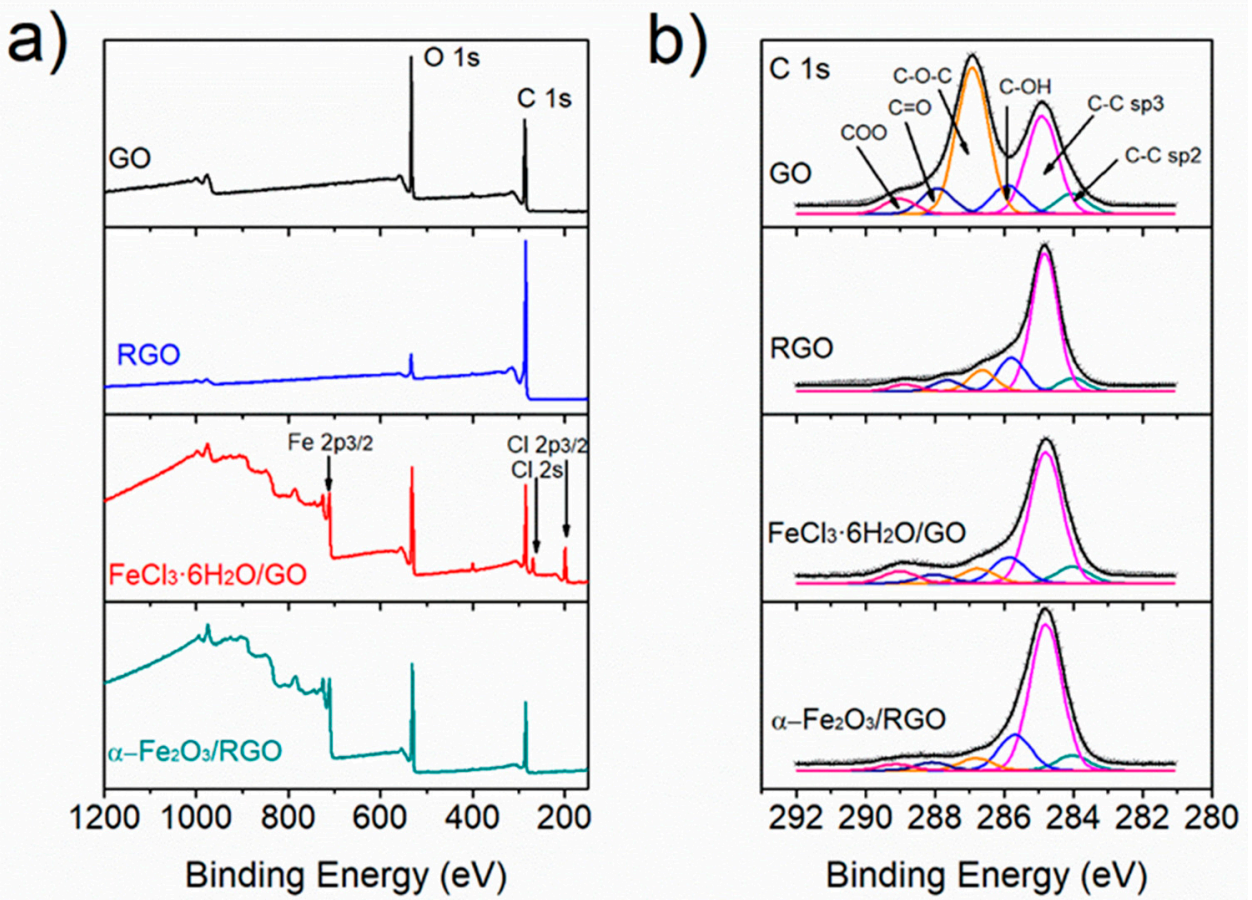

Figure 4. X-ray photoelectron spectroscopy (XPS) analysis of GO, RGO, $\mathrm{FeCl}_{3} \cdot 6 \mathrm{H}_{2} \mathrm{O} / \mathrm{GO}$, and $\alpha-\mathrm{Fe}_{2} \mathrm{O}_{3} / \mathrm{RGO}$ hybrid material. (a) Survey spectra and (b) spectra of $\mathrm{C} 1$ s core. 
The spectra $\mathrm{C}$ 1s core for GO, $\mathrm{RGO}, \mathrm{FeCl}_{3} \cdot 6 \mathrm{H}_{2} \mathrm{O} / \mathrm{GO}$, and $\alpha-\mathrm{Fe}_{2} \mathrm{O}_{3} / \mathrm{RGO}$ (Figure $4 \mathrm{~b}$ ) were deconvoluted into six components at $284 \mathrm{eV}, 284.8 \mathrm{eV}, 285.7 \mathrm{eV}, 286.8 \mathrm{eV}, 288.1 \mathrm{eV}$, and $289.1 \mathrm{eV}$ assigned to the following electronic environments: carbon atoms $\mathrm{C}-\mathrm{C}\left(\mathrm{sp}^{2}\right.$ and $\left.\mathrm{sp}^{3}\right), \mathrm{C}-\mathrm{OH}, \mathrm{C}-\mathrm{O}-\mathrm{C}$, $\mathrm{C}=\mathrm{O}$, and $\mathrm{COO}$, respectively [33]. The intensity of each component is associated with its chemical abundance and after the thermal treatment, the relative contribution of $\mathrm{C}-\mathrm{C}$ components increased, whereas the components associated with oxygen functional groups decreased due to the thermal reduction of $\mathrm{GO}$ through elimination of $\mathrm{CO}, \mathrm{CO}_{2}$, and $\mathrm{H}_{2} \mathrm{O}$ leading to restacking and loss of mass [34]. This can be seen in the relative composition of carbon species in the samples (Table S1). The results show oxygen functionalities in $\alpha-\mathrm{Fe}_{2} \mathrm{O}_{3} /$ RGO hybrid material that in turn promote the interaction with other molecules. In addition, despite the fact that no reduction treatment was carried out during the preparation of $\mathrm{FeCl}_{3} \cdot 6 \mathrm{H}_{2} \mathrm{O} / \mathrm{GO}$ paper, the intensity of $\mathrm{C}-\mathrm{O}-\mathrm{C}$ component in the $\mathrm{C} 1$ s spectrum $(6.9 \%)$ is closer to that in RGO (9.4\%) than in the GO spectrum (44\%) possibly due to the anchoring of $\mathrm{Fe}^{+3}$ ions on GO functionalities. This was further corroborated by the analysis of the $\mathrm{O} 1$ s core spectra (Figure S2a) where a contribution of Fe-O is observed in the chemical structure of $\mathrm{FeCl}_{3} \cdot 6 \mathrm{H}_{2} \mathrm{O} / \mathrm{GO}$ material. The analysis of the $\mathrm{Fe} 2 \mathrm{p}$ core spectra for the $\mathrm{FeCl}_{3} \cdot 6 \mathrm{H}_{2} \mathrm{O} / \mathrm{GO}$ and $\alpha-\mathrm{Fe}_{2} \mathrm{O}_{3} / \mathrm{RGO}$ materials shows the presence of $\mathrm{Fe}^{+3}$ (Figure S2b). Details of the chemical composition of the materials as well the surface area measurement of the $\mathrm{RGO}$ and $\alpha-\mathrm{Fe}_{2} \mathrm{O}_{3} / \mathrm{RGO}$ via nitrogen gas adsorption yielded a Brunauer, Emmett, and Teller (BET) is presented in the Table S1, and the $\mathrm{N}_{2}$ isotherm adsorption curves can be seen in Figure S3.

\subsection{Tetracycline Adsorption Studies}

The kinetics of adsorption of tetracycline on RGO as control and $\alpha-\mathrm{Fe}_{2} \mathrm{O}_{3} / \mathrm{RGO}$ hybrid material were studied under different $\mathrm{pH}$ (Figure 5) and under those conditions (pHs 4, 7, and 10), tetracycline hydrochloride solution is stable, and no precipitation was observed. The kinetics curves, plotting the amount of tetracycline adsorbed $\left(\mathrm{q}_{\mathrm{t}}, \mathrm{mg} / \mathrm{g}\right)$ in time, show that equilibrium is reached after $30 \mathrm{~min}$ showing maximum adsorption at $\mathrm{pH} 7$ for the $\alpha-\mathrm{Fe}_{2} \mathrm{O}_{3} / \mathrm{RGO}$ and $\mathrm{RGO}$ system. The adsorption kinetics was modeled using the pseudo-second-order model the parameters for each system are presented in Table S2. The pseudo-second-order model was chosen due to its wide use for the adsorption of organic pollutants on graphene-based adsorbents and because it assumes that the rate-limiting step involves chemisorption [16]. Several reports show that the charge of TC depends on $\mathrm{pH}$ value and can exist as a cationic, zwitterionic, and anionic species under acidic, moderately acidic to neutral, and alkaline conditions [35]. However, the capability of adsorption of TC on RGO depends also on the specific surface area, and the amount of remaining carboxylic groups that provide ionization groups in RGO and both features can be tuned by the reduction and activation process. In this case, since no additional activation was carried out, tetracycline adsorption could be driven by $\pi-\pi$ interactions and cation $-\pi$ bonding. Results show that the amount of remaining functional groups in RGO leads to an adsorption of $38.55 \mathrm{mg} / \mathrm{g}, 32.88 \mathrm{mg} / \mathrm{g}$, and $14.58 \mathrm{mg} / \mathrm{g}$ of TC at pH 7, 10, and 4, respectively, but decreased at $29.33 \mathrm{mg} / \mathrm{g}, 29.85 \mathrm{mg} / \mathrm{g}$, and $3.21 \mathrm{mg} / \mathrm{g}$ at $\mathrm{pH} \mathrm{7,10}$, and 4, respectively, when $\alpha-\mathrm{Fe}_{2} \mathrm{O}_{3} / \mathrm{RGO}$ was used as adsorbent under these experimental conditions; $25^{\circ} \mathrm{C}$ and $0.6 \mathrm{mg} / \mathrm{ml}$ of adsorbent and initial tetracycline concentration of $8.25 \mathrm{mg} / \mathrm{L}, 10.09 \mathrm{mg} / \mathrm{L}, 12.66 \mathrm{mg} / \mathrm{L}$ for $\mathrm{pH} 10, \mathrm{pH}$ 7, and $\mathrm{pH} 4$ respectively, since the kinetics parameters are affected by the initial concentration of tetracycline and the concertation ratio of adsorbent and adsorbate [16]. A higher initial concentration might increase competition between TC molecules for given adsorption sites on $\alpha-\mathrm{Fe}_{2} \mathrm{O}_{3} / \mathrm{RGO}$ accordingly a lower $\mathrm{K}_{2}$ value was obtained (Table S2). The decrease in adsorption compared with RGO material could be attributed to the decreasing of oxygen functional groups, and the presence of $\alpha-\mathrm{Fe}_{2} \mathrm{O}_{3}$ nanoparticles on RGO active sites. Thermal reduction of GO results in loss of oxygen functional groups that increased the positive charge of the molecule, while the presence of $\alpha-\mathrm{Fe}_{2} \mathrm{O}_{3}$ hindered the electrostatic interaction between the adsorbent and the tetracycline and the removal efficiency of the tetracycline decreased on $\alpha-\mathrm{Fe}_{2} \mathrm{O}_{3} /$ RGO material. 

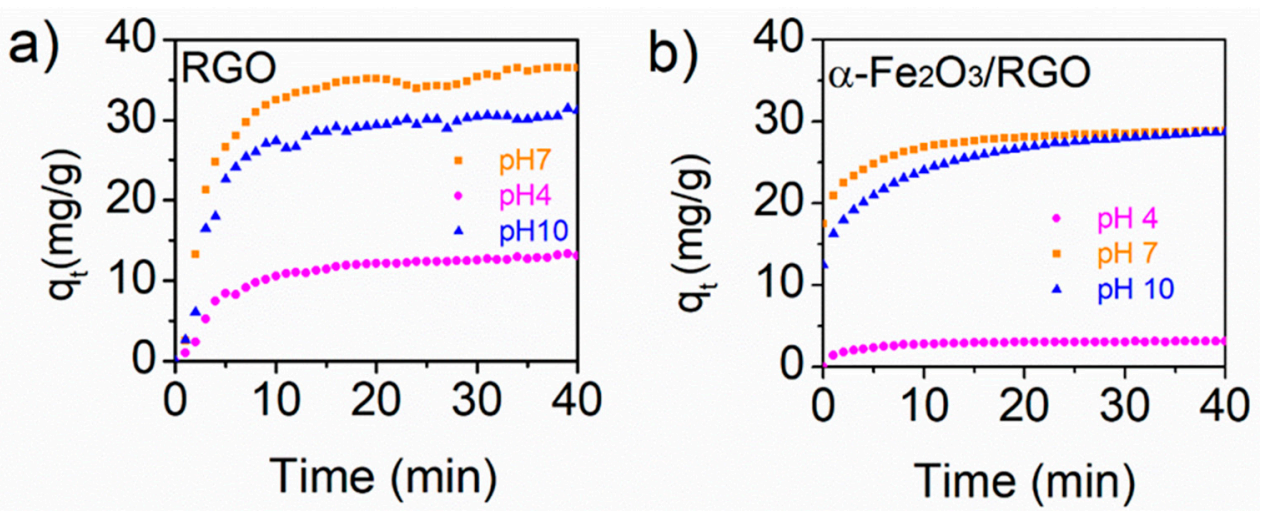

Figure 5. (a) Kinetic adsorption of tetracycline on RGO and (b) on $\alpha-\mathrm{Fe}_{2} \mathrm{O}_{3} / \mathrm{RGO}$ hybrid material as a function of $\mathrm{pH}$.

Thermodynamics of the adsorption studies was carried out obtaining isotherms as a function of $\mathrm{pH}$ of the media. The concentration of tetracycline varied from 25 to $5 \mathrm{mg} / \mathrm{L}$ and the amount of the tetracycline adsorbed on the $\alpha-\mathrm{Fe}_{2} \mathrm{O}_{3} / \mathrm{RGO}$ hybrid material and the remaining tetracycline in the solution were recorded after $2 \mathrm{~h}$. The resulting adsorption data were fitted with the Langmuir model which relates the amount of adsorbate adsorbed per unit weight of adsorbent $\left(q_{e}, \mathrm{mg} / \mathrm{g}\right)$ and the concentrations of adsorbate in the bulk solution $\left(C_{e}, \mathrm{mg} / \mathrm{L}\right)$ at a given temperature under equilibrium conditions (Table S2). The Langmuir model [36] assumes uniform energies of adsorption on the surface and no transmigration of adsorbate in the plane of the surface. It is linearly expressed as:

$$
\frac{C_{e}}{q_{e}}=\frac{1}{Q_{\max } K_{L}}+\frac{C_{e}}{Q_{\max }}
$$

where $Q_{\max }$ y $K_{L}$ are Langmuir constants related to the maximum adsorption capacity $(\mathrm{mg} / \mathrm{g}$ ) and the adsorption energy $(\mathrm{L} / \mathrm{mg})$, respectively. Adsorption data were also fitted with the Freundlich model [37], that assumes heterogeneous adsorption and multilayers. It can be expressed linearly as:

$$
\log q_{e}=\log K_{f}+\frac{1}{n} \log C_{e}
$$

where $k_{F}$ is the constant of Freundlich and $\mathrm{n}$ is the heterogeneity factor associated with the adsorption capacity.

The results indicated that the adsorption data fitted reasonably with Langmuir and Freundlich isotherms (Figure 6). However, RGO isotherms fitted very well with the Freundlich model whereas the adsorption isotherm for $\alpha-\mathrm{Fe}_{2} \mathrm{O}_{3} / \mathrm{RGO}$ fits better with the Langmuir model. Table 2 presents the kinetics constants associated with the isotherms evaluated at different $\mathrm{pH}$ values. The value of $\mathrm{n}$ constant for RGO isotherms range between one to two, which indicates heterogeneity in the adsorption capacity owing to the edges, multilayer structure for restacking, and different $\mathrm{sp}^{2}$ and $\mathrm{sp}^{3}$ domains in RGO. The $\mathrm{n}$ constant values for $\alpha-\mathrm{Fe}_{2} \mathrm{O}_{3} / \mathrm{RGO}$ isotherms fitted with the Freundlich model were larger than two for all the analyzed $\mathrm{pH}$ values, which indicates that this adsorbent exhibit a surface heterogeneity owing the presence of two phases, RGO and $\alpha-\mathrm{Fe}_{2} \mathrm{O}_{3}$ nanoparticles each one with different surface chemistry. Then the results show the disturbance of the adsorption of tetracycline by the presence of different surface chemistries in the adsorbent layer which resulted in low adsorption efficiency. This agrees with the constants obtained from the fitting with the Langmuir model, the maximum adsorption $\left(Q_{\max }, \mathrm{mg} / \mathrm{g}\right.$ ) of $\mathrm{RGO}$ isotherms were $44.23 \mathrm{mg} / \mathrm{g}, 39.94 \mathrm{mg} / \mathrm{g}$, and $15.82 \mathrm{mg} / \mathrm{g}$ at $\mathrm{pH} 7,10$, and 4 , respectively. The $Q_{\max }$ for the $\alpha-\mathrm{Fe}_{2} \mathrm{O}_{3} / \mathrm{RGO}$ decreased to $9.69 \mathrm{mg} / \mathrm{g}, 10.25 \mathrm{mg} / \mathrm{g}$, and $18.48 \mathrm{mg} / \mathrm{g}$ at $\mathrm{pH} 7,10$, and 4, respectively, the decreasing is related to the modified functionalities in RGO surface by adding nanoparticles with wide particle size hindering the active sites of RGO. The maximum adsorption of tetracycline on $\alpha-\mathrm{Fe}_{2} \mathrm{O}_{3} / \mathrm{RGO}$ was observed under 
$\mathrm{pH} 4$ and agrees with previous reports for chemisorbing. The adsorption results are lower than those reported for GO in the literature (Table 1). Unlike RGO, GO has a higher abundance of functional groups, such as carboxylic, phenolic, hydroxyl, and epoxy groups. These groups provide GO with water dispersibility and stabilize the carboxylate group favored the electric charge needed for the chemisorption of tetracycline. In addition, the results also show that $\alpha-\mathrm{Fe}_{2} \mathrm{O}_{3}$ nanoparticles on RGO hindered tetracycline adsorption. Additional studies can be performed to improve the adsorption capability by activating the surface and to find the optimum conditions to tetracycline adsorption by modifying adsorption conditions, such as ion strength.
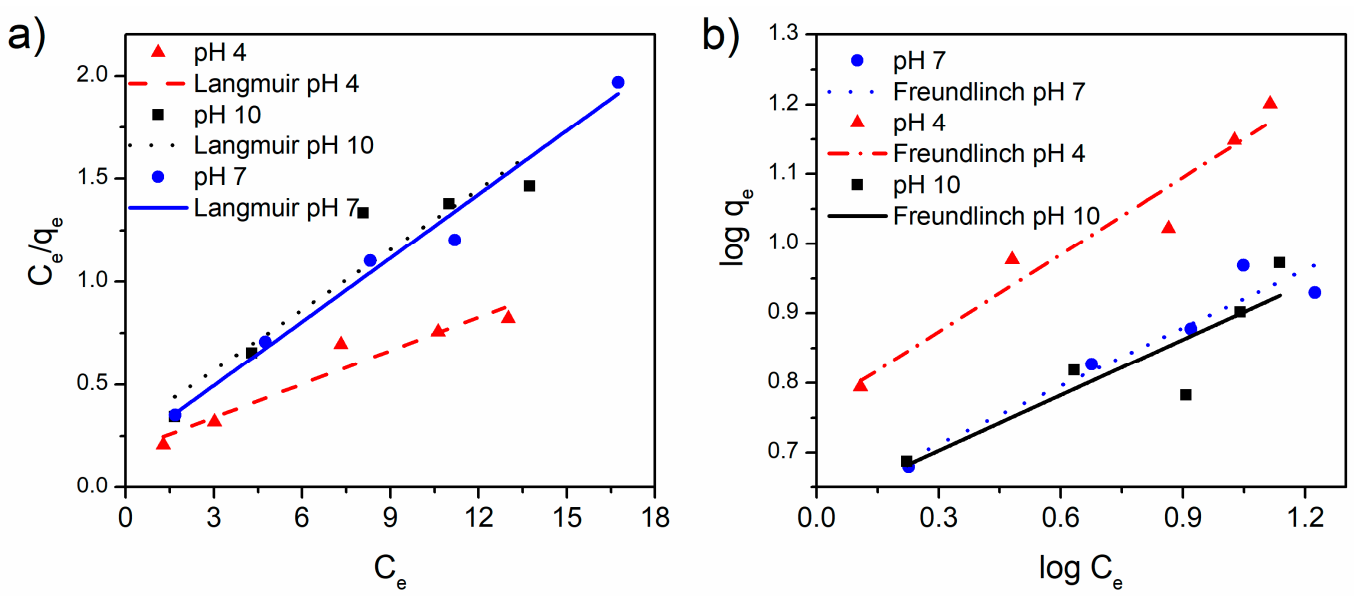

Figure 6. (a) Langmuir and (b) Freundlich model fitting for the adsorption of tetracycline on $\alpha-\mathrm{Fe}_{2} \mathrm{O}_{3} / \mathrm{RGO}$ hybrid material. Experiment condition: $25^{\circ} \mathrm{C} ; 0.7 \mathrm{mg} / \mathrm{mL}$ of adsorbent.

Table 2. Langmuir and Freundlich adsorption isotherms fitting parameters of tetracycline on $\alpha-\mathrm{Fe}_{2} \mathrm{O}_{3} /$ RGO and RGO as control.

\begin{tabular}{cccccccc}
\hline \multirow{2}{*}{ Adsorbent } & \multicolumn{4}{c}{ Langmuir } & \multicolumn{4}{c}{ Freundlich } \\
\cline { 2 - 8 } & $\mathbf{p H}$ & $\boldsymbol{Q}_{\max }(\mathbf{m g} / \mathbf{g})$ & $\boldsymbol{K}_{\boldsymbol{L}} \mathbf{( L / m g )}$ & $\mathbf{r}^{\mathbf{2}}$ & $\boldsymbol{n}$ & $\boldsymbol{K}_{\boldsymbol{F}} \mathbf{( \mathbf { L } / \mathbf { m g } )}$ & $\mathbf{r}^{\mathbf{2}}$ \\
\hline \multirow{2}{*}{$\alpha-\mathrm{Fe}_{2} \mathrm{O}_{3} / \mathrm{RGO}$} & 4 & 18.48 & 0.30 & 0.965 & 2.71 & 5.79 & 0.971 \\
& 7 & 9.69 & 0.56 & 0.991 & 3.60 & 4.26 & 0.958 \\
& 10 & 10.25 & 0.35 & 0.945 & 3.77 & 4.20 & 0.894 \\
\hline \multirow{2}{*}{$\mathrm{RGO}$} & 4 & 15.82 & 0.05 & 0.921 & 1.44 & 0.99 & 0.993 \\
& 7 & 44.23 & 0.09 & 0.975 & 1.57 & 4.65 & 0.999 \\
& 10 & 39.94 & 0.07 & 0.994 & 1.31 & 2.83 & 0.995 \\
\hline
\end{tabular}

\subsection{Magnetic Characterization of $\alpha-\mathrm{Fe}_{2} \mathrm{O}_{3} / \mathrm{RGO}$ Nanocomposites}

Figure S5 shows the measurement of the temperature dependence of magnetization of the $\alpha-\mathrm{Fe}_{2} \mathrm{O}_{3} / \mathrm{RGO}$ nanocomposites (Figure S5a) and the ferromagnetic character of the $\alpha-\mathrm{Fe}_{2} \mathrm{O}_{3}$ nanoparticles with a Curie temperature of $567^{\circ} \mathrm{C}$. The magnetic hysteresis curves were recorded at $300 \mathrm{~K}$ (room temperature). Figure S5b indicates a saturation magnetization $\mathrm{Ms}=7.15 \mathrm{Am}^{2} / \mathrm{kg}$, a remanence of $\mathrm{Mr}=2.29 \mathrm{Am}^{2} / \mathrm{kg}$, and a coercive field of $\mathrm{Hc}=0.02 \mathrm{~T}$. The magnetic intensities are low due to the presence of RGO and the small size of the $\alpha-\mathrm{Fe}_{2} \mathrm{O}_{3}$ nanoparticles. In addition, the hematite in the bulk form is antiferromagnetic with a weak ferromagnetism above the Morin transition and below its Néel temperature. However, the ferromagnetic behavior of the hematite at nano size has often been reported in literature due to the magnetic domain size which is reached at about $40 \mathrm{~nm}$, but it is also affected by the morphology and crystal structure [38,39]. In the morphology analysis (Figure 3), a wide particle size distribution of $\alpha-\mathrm{Fe}_{2} \mathrm{O}_{3}$ nanoparticles on the RGO surface can be seen, and also a large number of small nanoparticles $(<10 \mathrm{~nm})$, which are expected to have the monodomain size and exhibit ferromagnetic/superparamagnetic behavior dependent of the particle 
size [39]. According to the magnetic studies $\alpha-\mathrm{Fe}_{2} \mathrm{O}_{3} / \mathrm{RGO}$, nanocomposites exhibit a ferromagnetic behavior with small coercivity and remnant magnetization at room temperature, which is desirable for many practical applications, such as water purification systems, as it can be removed from the contaminated water. Figure 7 presents $\alpha-\mathrm{Fe}_{2} \mathrm{O}_{3} / \mathrm{RGO}$ hybrid material dispersed in a pH 4 buffer solution placed beside RGO dispersion as control. The hybrid material was separated after being exposed to the magnetic field. However, additional studies should be done since $\alpha-\mathrm{Fe}_{2} \mathrm{O}_{3}$ nanoparticles reduce the adsorption capability of RGO. The magnetization is probably enough to allow magnetic separation in laboratory-scale systems but might not be high enough to allow separation in large wastewater volumes.
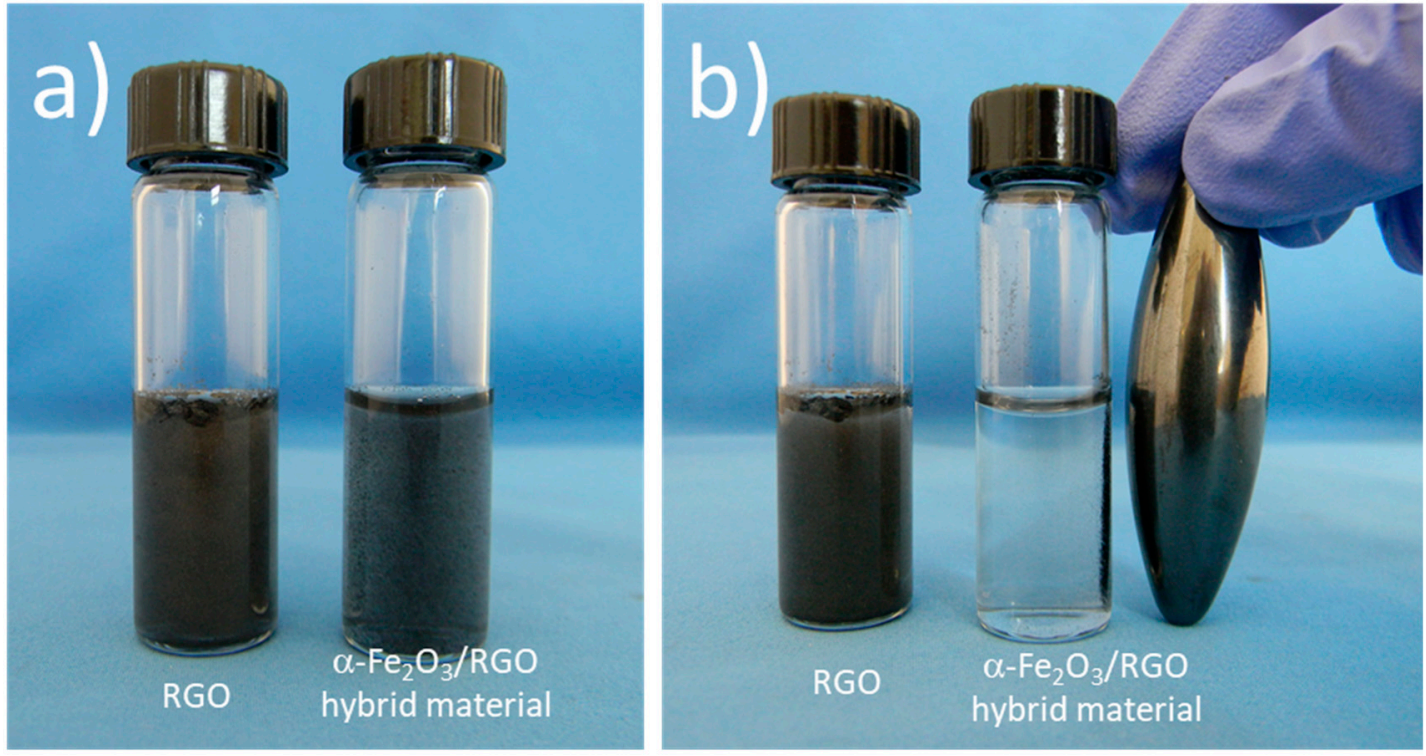

Figure 7. Pictures of RGO and $\alpha-\mathrm{Fe}_{2} \mathrm{O}_{3} / \mathrm{RGO}$ hybrid material dispersion in $\mathrm{pH} 4$ buffer solution (a) before and (b) after exposing a magnetic field.

\section{Conclusions}

Hybrid nanomaterials of RGO with $\alpha-\mathrm{Fe}_{2} \mathrm{O}_{3}$ nanoparticles were prepared in situ by thermal treatment. The structural and morphology studies show that reduction of oxygen functional groups in RGO, after thermal treatment, and the presence of $\alpha-\mathrm{Fe}_{2} \mathrm{O}_{3}$ nanoparticles on RGO surface impact the surface chemistry. The tetracycline adsorption on $\mathrm{RGO}$ depended on the $\mathrm{pH}$ value, and the maximum adsorption was $38.55 \mathrm{mg} / \mathrm{g}, 32.88 \mathrm{mg} / \mathrm{g}$, and $14.58 \mathrm{mg} / \mathrm{g}$ at $\mathrm{pH}$ of 7, 10, and 4, respectively, in accordance with the Langmuir isotherm model. The adsorption kinetics fit well with the pseudo-second-order kinetic model. $\alpha-\mathrm{Fe}_{2} \mathrm{O}_{3}$ nanoparticles grew on adsorption sites on RGO then the adsorption of tetracycline on the $\alpha-\mathrm{Fe}_{2} \mathrm{O}_{3} / \mathrm{RGO}$ nanocomposite decreased. The $\alpha-\mathrm{Fe}_{2} \mathrm{O}_{3} / \mathrm{RGO}$ nanocomposites exhibited a ferromagnetic behavior at room temperature that enabled the separation of their aqueous dispersions by using a magnetic field. However, additional studies should be done to use magnetic separation of this material in large scale wastewater treatment.

Supplementary Materials: The following are available online at http:/ /www.mdpi.com/2079-4991/9/3/313/s1, Figure S1: FT-IR spectra of GO and RGO obtained after thermal treatment. Figure S2: XPS analysis of GO, RGO, $\mathrm{FeCl}_{3} 6 \mathrm{H}_{2} \mathrm{O} / \mathrm{GO}$, and $\alpha-\mathrm{Fe}_{2} \mathrm{O}_{3} / \mathrm{RGO}$ hybrid material. (a) Spectra of O1s core and (b) Spectra Fe2p core. Figure S3: $\mathrm{N} 2$ adsorption-desorption isotherms for $\mathrm{RGO}$ and $\alpha-\mathrm{Fe}_{2} \mathrm{O}_{3} / \mathrm{RGO}$ hybrid materials. Figure S4: Experimental curves of $t$ /qt vs. $t$ for the adsorption of TC on (a) RGO and (b) $\alpha-\mathrm{Fe}_{2} \mathrm{O}_{3} / \mathrm{RGO}$ hybrid materials. Figure S5: Magnetic study of $\alpha-\mathrm{Fe}_{2} \mathrm{O}_{3} /$ RGO nanocomposites. (a) Temperature dependence of magnetization at a field of $40 \mathrm{kA} / \mathrm{m}$ and (b) hysteresis loop at room temperature for magnetic field up to $2 \mathrm{~T}$. Table S1: Chemical composition from XPS analysis. Table S2: Parameters of pseudo-second-order kinetics for Tetracycline Adsorption on RGO and $\alpha-\mathrm{Fe}_{2} \mathrm{O}_{3} / \mathrm{RGO}$ hybrid materials. Table S3: Experimental data of adsorption properties of tetracycline on $\alpha-\mathrm{Fe}_{2} \mathrm{O}_{3} / \mathrm{RGO}$ hybrid materials: the amount of adsorbate adsorbed per unit weight of adsorbent $\left(q_{e}, \mathrm{mg} / \mathrm{g}\right)$ and the concentrations of adsorbate in the bulk solution $\left(C_{e}, \mathrm{mg} / \mathrm{L}\right)$ at a given temperature under equilibrium conditions. 
Author Contributions: Conceptualization, R.C.-S. and S.S.-G.; methodology, A.M.H.-F. and C.A.-F.; formal analysis, A.M.-d.-1.C., and J.M.B.; writing-original draft preparation, A.M.H.-F.; writing-review and editing, S.S.-G. and R.C.-S.

Funding: This research was funded by CONACYT-MEX, grant number 239354.

Acknowledgments: Rodolfo Cruz-Silva acknowledges the support from the Center of Innovation (COI) Program "Global Aqua Innovation Center for Improving Living Standards and Water-sustainability" from Japan Science and Technology Agency, JST. Authors thank M. Nava for the specific surface area measurements of the materials.

Conflicts of Interest: The authors declare no conflict of interest.

\section{References}

1. Aminov, R. History of antimicrobial drug discovery: Major classes and health impact. Biochem. Pharmacol. 2017, 133, 4-19. [CrossRef] [PubMed]

2. Rose, W.E.; Rybak, M.J. Tigecycline: First of a New Class of Antimicrobial Agents. Pharmacotherapy 2006, 26, 1099-1110. [CrossRef] [PubMed]

3. Gothwal, R.; Shashidhar, T. Antibiotic Pollution in the Environment: A. Review. CLEAN-Soil Air Water 2015, 43, 479-489. [CrossRef]

4. Zhang, X.-X.; Zhang, T.; Fang, H.H.P. Antibiotic resistance genes in water environment. Appl. Microbiol. Biotechnol. 2009, 82, 397-414. [CrossRef] [PubMed]

5. Du, L.; Liu, W. Occurrence, fate, and ecotoxicity of antibiotics in agro-ecosystems. A review. Agron. Sustain. Dev. 2012, 32, 309-327. [CrossRef]

6. Le-Minh, N.; Khan, S.J.; Drewes, J.E.; Stuetz, R.M. Fate of antibiotics during municipal water recycling treatment processes. Water Res. 2010, 44, 4295-4323. [CrossRef] [PubMed]

7. Ahmed, M.B.; Zhou, J.L.; Ngo, H.H.; Guo, W. Adsorptive removal of antibiotics from water and wastewater: Progress and challenges. Sci. Total Environ. 2015, 532, 112-126. [CrossRef] [PubMed]

8. Yu, F.; Li, Y.; Han, S.; Ma, J. Adsorptive removal of antibiotics from aqueous solution using carbon materials. Chemosphere 2016, 153, 365-385. [CrossRef] [PubMed]

9. Ahmed, M.J. Adsorption of quinolone, tetracycline, and penicillin antibiotics from aqueous solution using activated carbons: Review. Environ. Toxicol. Pharmacol. 2017, 50, 1-10. [CrossRef] [PubMed]

10. Singh, V.; Joung, D.; Zhai, L.; Das, S.; Khondaker, S.I.; Seal, S. Graphene based materials: Past, present and future. Prog. Mater. Sci. 2011, 56, 1178-1271. [CrossRef]

11. Edwards, R.S.; Coleman, K.S. Graphene synthesis: Relationship to applications. Nanoscale 2013, 5, 38-51. [CrossRef] [PubMed]

12. Marcano, D.C.; Kosynkin, D.V.; Berlin, J.M.; Sinitskii, A.; Sun, Z.; Slesarev, A.; Alemany, L.B.; Lu, W.; Tour, J.M. Improved Synthesis of Graphene Oxide. ACS Nano 2010, 4, 4806-4814. [CrossRef] [PubMed]

13. Becerril, H.A.; Mao, J.; Liu, Z.; Stoltenberg, R.M.; Bao, Z.; Chen, Y. Evaluation of Solution-Processed Reduced Graphene Oxide Films as Transparent Conductors. ACS Nano 2008, 2, 463-470. [CrossRef] [PubMed]

14. Ji, L.; Chen, W.; Duan, L.; Zhu, D. Mechanisms for strong adsorption of tetracycline to carbon nanotubes: A comparative study using activated carbon and graphite as adsorbents. Environ. Sci. Technol. 2009, 43, 2322-2327. [CrossRef] [PubMed]

15. Zhang, L.; Song, X.; Liu, X.; Yang, L.; Pan, F.; Lv, J. Studies on the removal of tetracycline by multi-walled carbon nanotubes. Chem. Eng. J. 2011, 178, 26-33. [CrossRef]

16. Gao, Y.; Li, Y.; Zhang, L.; Huang, H.; Hu, J.; Shah, S.M.; Su, X. Adsorption and removal of tetracycline antibiotics from aqueous solution by graphene oxide. J. Colloid Interf. Sci. 2012, 368, 540-546. [CrossRef] [PubMed]

17. Ghadim, E.E.; Manouchehri, F.; Soleimani, G.; Hosseini, H.; Kimiagar, S.; Nafisi, S. Adsorption Properties of Tetracycline onto Graphene Oxide: Equilibrium, Kinetic and Thermodynamic Studies. PLoS ONE 2013, 8, e79254. [CrossRef] [PubMed]

18. Chen, L.-C.; Lei, S.; Wang, M.-Z.; Yang, J.; Ge, X.-W. Fabrication of macroporous polystyrene/graphene oxide composite monolith and its adsorption property for tetracycline. Chin. Chem. Lett. 2016, 27, 511-517. [CrossRef] 
19. Feng, Y.; Huynh, K.A.; Xie, Z.; Liu, G.; Gao, S. Heteroaggregation and sedimentation of graphene oxide with hematite colloids: Influence of water constituents and impact on tetracycline adsorption. Sci. Total Environ. 2019, 647, 708-715. [CrossRef] [PubMed]

20. Tabrizian, P.; Ma, W.; Bakr, A.; Rahaman, M.S. pH-sensitive and magnetically separable Fe/Cu bimetallic nanoparticles supported by graphene oxide (GO) for high-efficiency removal of tetracyclines. J. Colloid Interf. Sci. 2019, 534, 549-562. [CrossRef] [PubMed]

21. Zhang, Y.; Chen, B.; Zhang, L.; Huang, J.; Chen, F.; Yang, Z.; Yao, J.; Zhang, Z. Controlled assembly of $\mathrm{Fe}_{3} \mathrm{O}_{4}$ magnetic nanoparticles on graphene oxide. Nanoscale 2011, 3, 1446-1450. [CrossRef] [PubMed]

22. Cao, M.; Wang, P.; Ao, Y.; Wang, C.; Hou, J.; Qian, J. Visible light activated photocatalytic degradation of tetracycline by a magnetically separable composite photocatalyst: Graphene oxide/magnetite/cerium-doped titania. J. Colloid Interface Sci. 2016, 467, 129-139. [CrossRef] [PubMed]

23. Shan, D.; Deng, S.; Zhao, T.; Wang, B.; Wang, Y.; Huang, J.; Yu, G.; Winglee, J.; Wiesner, M.R. Preparation of ultrafine magnetic biochar and activated carbon for pharmaceutical adsorption and subsequent degradation by ball milling. J. Hazard. Mater. 2016, 305, 156-163. [CrossRef] [PubMed]

24. Chen, S.-Q.; Chen, Y.-L.; Jiang, H. Slow Pyrolysis Magnetization of Hydrochar for Effective and Highly Stable Removal of Tetracycline from Aqueous Solution. Ind. Eng. Chem. Res. 2017, 56, 3059-3066. [CrossRef]

25. Hazell, G.; Hinojosa-Navarro, M.; McCoy, T.M.; Tabor, R.F.; Eastoe, J. Responsive materials based on magnetic polyelectrolytes and graphene oxide for water clean-up. J. Colloid Interface Sci. 2016, 464, 285-290. [CrossRef] [PubMed]

26. Huang, D.; Wu, J.; Wang, L.; Liu, X.; Meng, J.; Tang, X.; Tang, C.; Xu, J. Novel insight into adsorption and co-adsorption of heavy metal ions and an organic pollutant by magnetic graphene nanomaterials in water. Chem. Eng. J. 2019, 358, 1399-1409. [CrossRef]

27. Xiong, W.; Zeng, G.; Yang, Z.; Zhou, Y.; Zhang, C.; Cheng, M.; Liu, Y.; Hu, L.; Wan, J.; Zhou, C.; et al. Adsorption of tetracycline antibiotics from aqueous solutions on nanocomposite multi-walled carbon nanotube functionalized MIL-53(Fe) as new adsorbent. Sci. Total Environ. 2018, 627, 235-244. [CrossRef] [PubMed]

28. Anirudhan, T.S.; Deepa, J.R.; Nair, A.S. Fabrication of chemically modified graphene oxide/nano hydroxyapatite composite for adsorption and subsequent photocatalytic degradation of aureomycine hydrochloride. J. Ind. Eng. Chem. 2017, 47, 415-430. [CrossRef]

29. Hu, X.; Zhao, Y.; Wang, H.; Tan, X.; Yang, Y.; Liu, Y. Efficient Removal of Tetracycline from Aqueous Media with a $\mathrm{Fe}_{3} \mathrm{O}_{4}$ Nanoparticles@graphene Oxide Nanosheets Assembly. Int. J. Environ. Res. Public Health 2017, 14, 1495. [CrossRef] [PubMed]

30. Yu, B.; Bai, Y.; Ming, Z.; Yang, H.; Chen, L.; Hu, X.; Feng, S.; Yang, S.-T. Adsorption behaviors of tetracycline on magnetic graphene oxide sponge. Mater. Chem. Phys. 2017, 198, 283-290. [CrossRef]

31. Song, L.; Khoerunnisa, F.; Gao, W.; Dou, W.; Hayashi, T.; Kaneko, K.; Endo, M.; Ajayan, P.M. Effect of high-temperature thermal treatment on the structure and adsorption properties of reduced graphene oxide. Carbon 2013, 52, 608-612. [CrossRef]

32. Ferrari, A.C. Raman spectroscopy of graphene and graphite: Disorder, electron-phonon coupling, doping and nonadiabatic effects. Solid State Commun. 2007, 143, 47-57. [CrossRef]

33. Hsiao, M.-C.; Ma, C.-C.M.; Chiang, J.-C.; Ho, K.-K.; Chou, T.-Y.; Xie, X.; Tsai, C.-H.; Chang, L.-H.; Hsieh, C.-K. Thermally conductive and electrically insulating epoxy nanocomposites with thermally reduced graphene oxide-silica hybrid nanosheets. Nanoscale 2013, 5, 5863-5871. [CrossRef] [PubMed]

34. Botas, C.; Álvarez, P.; Blanco, C.; Santamaría, R.; Granda, M.; Gutiérrez, M.D.; Rodríguez-Reinoso, F.; Menéndez, R. Critical temperatures in the synthesis of graphene-like materials by thermal exfoliation-reduction of graphite oxide. Carbon 2013, 52, 476-485. [CrossRef]

35. Gu, C.; Karthikeyan, K.G.; Sibley, S.D.; Pedersen, J.A. Complexation of the antibiotic tetracycline with humic acid. Chemosphere 2007, 66, 1494-1501. [CrossRef] [PubMed]

36. Langmuir, I. The adsorption of gases on plane surfaces of glass, mica and platinum. J. Am. Chem. Soc. 1918, 40, 1361-1403. [CrossRef]

37. Freundlich, H. Über die Adsorption in Lösungen. In Zeitschrift für Physikalische Chemie; Oldenbourg Wissenschaftsverlag: Berlin, Germany, 1907; Volume 57, pp. 385-470. 
38. Raming, T.P.; Winnubst, A.J.A.; van Kats, C.M.; Philipse, A.P. The Synthesis and Magnetic Properties of Nanosized Hematite $\left(\alpha-\mathrm{Fe}_{2} \mathrm{O}_{3}\right)$ Particles. J. Colloid Interface Sci. 2002, 249, 346-350. [CrossRef] [PubMed]

39. Malaidurai, M.; Thangavel, R. Study of structural and magnetic properties of co-precipitated $\alpha-\mathrm{Fe}_{2} \mathrm{O}_{3}$ nanocrystals. Superlattice. Microst. 2018, 120, 553-560. [CrossRef] 